\title{
No entorno de escombros: notas acidentais sobre o trauma dos judeus de Salônica
}

\section{Among ruins: accidental notes on the trauma of Salonican Jewry}

Gabriel Mordoch*

Resumo: Baseando-se em fontes publicadas em inglês, francês, espanhol, judeu-espanhol (ladino), português e hebraico, este ensaio discute a Shoá (Holocausto) em Salônica (Tessalônica), Grécia, enfocando especificamente o trauma vivido pelos sobreviventes e seus descendentes. $\mathrm{O}$ ensaio também aborda temas ainda insuficientemente pesquisados, como a extrema pobreza entre os judeus de Thessaloniki às vésperas da Segunda Guerra Mundial, bem como a participação judaica no Exército grego na luta contra os italianos na frente albanesa em 1940-1941. Além disso, o estudo traz à luz histórias pessoais não publicadas de judeus de Thessaloniki que sobreviveram à destruição praticamente completa de sua comunidade durante a Segunda Guerra Mundial.

Palavras-chave: Salônica (Tessalônica). Shoá (Holocausto). Segunda Guerra Mundial. Grécia. Albânia. Sobreviventes.

\begin{abstract}
Drawing upon published sources in English, French, Spanish, Judeo-Spanish (Ladino), Portuguese, and Hebrew, this essay discusses the Shoah (Holocaust) in Thessaloniki, Greece, focusing specifically on the trauma experienced by survivors and their descendants. The essay also addresses topics that have been insufficiently researched so far, such as the extreme poverty among the Jews of Thessaloniki on the eve of World War II, as well as the Jewish participation in the Greek Army in the fight against the Italians on the Albanian front in 1940-1941. In addition, the essay brings to light unpublished personal stories of Jews from Thessaloniki who survived the almost complete destruction of their community during World War II.
\end{abstract}

Key words: Thessaloniki. Shoah (Holocaust). World War II. Greece. Albania. Survivors.

"Treinta años después de mi primera visita turística volví a Salónica.
Al comprobar la casi completa defunción de la sociedad y hasta de la
cultura sefardí, por lo menos en los lugares más importantes de su largo
historial, los pocos conocedores por experiencia directa, o los
aficionados a sus historias olvidadas, experimentan una atracción entre

*Doutor em Estudos Lusófonos pela Ohio State University.
Email: <mordoch@umich.edu>. 
lo arqueológico y lo sentimental hacia el tiempo y el mundo perdido. En este viaje de la añoranza, Salónica es una etapa obligada”.

Isaac Papo, Viaje en el ocaso de una cultura ibérica, p. 322.

Desde a perspectiva privilegiada dos dias de hoje, no aconchego de nossos lares e distância implacável do tempo, é difícil deixar de perceber o destino singular dos judeus de Salônica como uma sucessão de tragédias anunciadas. Esta série de tragédias culminaria de modo catastrófico com a aniquilação de cerca de $96 \%$ da comunidade, deportada para os campos da morte em dezenove comboios de trens que partiram da estação adjacente ao gueto Baron Hirsch entre março e agosto de 1943. É verdade que a história poderia ter sido diferente, mas lamentavelmente não foi. A realidade atroz dos fatos, por si só capaz de gerar calafrios inclusive nos mais incrédulos, torna-se ainda mais pungente quando reconhecemos que o princípio do século XX parecia promissor para a comunidade judaica de Salônica, tanto em termos demográficos como culturais e socioeconômicos. A emblemática cidade portuária balcânica situada na região macedônia, à beira do mar Egeu, contava então com cerca de 80.000 residentes de fé mosaica, os quais compunham aproximadamente metade da população total de Salônica - que naquele então ainda era administrada pelo império otomano e habitada por uma população diversa composta por judeus, muçulmanos e cristãos de variadas origens étnicas.

Por incrível que pareça, a população judaica predominava numericamente em Salônica desde o fim do século XV em virtude do grande número de sefardim (judeus de origem ibérica) residindo na cidade. Por haver acolhido os sefardim prófugos de Espanha e Portugal, emigrados em decorrência dos traumáticos éditos de expulsão e conversão promulgados pelos reis católicos em 1492 e 1497, Salônica ficou conhecida como a "Jerusalém dos Bálcãs" e "madre do judaísmo", conforme o dizer do cristão-novo lusitano Samuel Usque (1500-1555), ele mesmo filho do desterro de Portugal (USQUE, 1553, f. 208-209). De fato, é possível argumentar que o esplendor da presença sefardita em Salônica nasceu justamente em decorrência de um trauma coletivo: a conversão forçada e subsequente exílio de uma numerosa comunidade que havia séculos habitava a península ibérica. No final do século XV Salônica contava com 29.000 residentes, entre os quais cerca da metade eram judeus, a maioria de origem ibérica (MOLHO, 2003, p. 13). Em 1613, dois terços da população total da cidade era constituída por judeus (MELAMMED, 2013, p. 1). Na hipótese ousada de Nancy Kobrin (2009), os ecos traumáticos da conversão, exílio e o desenvolvimento de uma identidade criptojudaica entre os sefardim reverberariam séculos depois nas teorias psicoanalíticas elaboradas 
por Sigmund Freud. De qualquer maneira, o presente ensaio não se ocupa da instalação de judeus e conversos sefardim em Salônica durante os primórdios da modernidade, estudada com riqueza de detalhes por Jane S. Gerber (2020) e outros, nem do famigerado doutor vienense, mas dos traumas multidimensionais enfrentados pelos integrantes dessa comunidade sui generis e seus descendentes após a Shoá (Holocausto). Antes de mais nada, convém refletir brevemente sobre o contexto que antecedeu a deportação e aniquilação da comunidade. Tal reflexão, aliás, também proporciona a oportunidade de avançar a hipótese do pauperismo de grande parte da comunidade judaica salonicense como um dos fatores que limitou consideravelmente sua capacidade de reação ante o desenrolar dos fatos, de modo a facilitar o rápido e praticamente completo extermínio da comunidade. Em números absolutos, a Shoá em Salônica não cobrou tantas vidas quanto no leste europeu. Não obstante, em termos proporcionais o estrago causado na cidade balcânica foi similar ao ocorrido entre as comunidades polonesas mais castigadas pelo aparato mortífero criado pelo regime nazista e seus colaboradores. ${ }^{1}$

\section{Incorporação ao estado grego}

Após cerca de quinhentos anos sob contínuo controle otomano, Salônica foi capturada pelo exército grego em outubro de 1912 no contexto das chamadas guerras balcânicas (19121913), ocasião na qual a Sublime Porta perdeu praticamente todas suas possessões territoriais europeias, incluindo-se a região macedônia, anexada pela Grécia, cujo território por sua vez dobrou de tamanho. Com o advento do governo helênico, Salônica passou a ser chamada oficialmente por seu nome grego, Thessaloniki. A crise deflagrada com o estabelecimento do governo grego veio acompanhada pelo receio de políticas sociais destinadas a privilegiar grupos étnicos cristãos ortodoxos gregos, bem como do temor de atitudes anti-judaicas. Tudo isso aparentemente impeliu 450 judeus salonicenses a solicitar cidadania austríaca. Adicionalmente, 750 integrantes da comunidade judaica de Salônica tornaram-se cidadãos espanhóis e 1.200 cidadãos portugueses, na esperança de garantir proteção enquanto estrangeiros vivendo na Grécia (MOLHO, 1988, p. 395). De fato, décadas depois muitos deles se salvariam das deportações para os campos da morte justamente pelo fato de portarem um passaporte estrangeiro. $^{2}$

\footnotetext{
${ }^{1}$ Sobre a destruição de comunidades sefarditas durante a Shoá conferir Isaac Jack Lévy (2020).

${ }^{2}$ Sobre os judeus gregos que solicitaram cidadania espanhola conferir Haim Avni (1982). 
Uma vez que os sefardim haviam se estabelecido em Salônica no fim do século XV a convite de sultões otomanos, sua presença na cidade poderia ser equacionada, desde a perspectiva do novo regime grego, ao domínio otomano que havia perdurado por quase cinco séculos, gerando assim ressentimentos por parte da população grega local. Adicionalmente, a incorporação da cidade a um estado-nação com fronteiras definidas complicava as atividades comerciais dos diversos setores da comunidade judaica salonicense, acostumados a negociar com entrepostos espalhados pela bacia mediterrânea e em diferentes áreas do império otomano. Não obstante, e apesar de alguns eventos anti-judaicos isolados, a incorporação da comunidade judaica de Salônica ao estado grego ocorreu de forma aparentemente harmônica. As tensões existiram sobretudo entre as diferentes linhas ideológicas da própria comunidade judaica socialistas, sionistas de variadas vertentes, tradicionalistas, industrialistas, proletários, francófilos etc. (MOLHO, 1998, p. 398-399). Contrariando a narrativa historiográfica que romantizou o período otomano enquanto uma "época de ouro", pesquisadores como Eyal Ginio (2002), Devin E. Naar (2018) e Shai Srougo (2020) argumentaram que a incorporação ao estado grego não implicou necessariamente em um "declínio" do esplendor da comunidade judaica de Salônica. Com efeito, é possível argumentar que o status de cidadãos da república helênica proporcionou oportunidades outrora inacessíveis para sefardim habitantes da Jerusalém dos Bálcãs, dando espaço, além do mais, para a formação de uma nova identidade greco-judaica. De qualquer maneira, um desastre ocorrido em 1917 alteraria radicalmente a fortuna dos habitantes da cidade, sobretudo os de fé mosaica.

\section{Incêndio e declínio demográfico}

Em agosto de 1917, um mês após a Grécia entrar na Primeira Guerra Mundial ao lado dos Aliados, Salônica sofreu um dos golpes mais traumáticos de sua história moderna. Um incêndio de grandes proporções arrasou boa parte da cidade, incluindo diversos bairros judaicos, muitos deles localizados em regiões centrais adjacentes ao porto. Não podemos dizer que o incêndio foi uma completa surpresa. Devido à localização geográfica entre o Mar Mediterrâneo e a península balcânica, Salônica encontra-se na intersecção entre duas zonas climáticas, de modo que enfrenta altas variações de pressão atmosférica ao longo do ano. Os fortes ventos que sopram do norte adentram a região via o vale do Rio Vardar facilitando a rápida propagação de incêndios (MAZOWER, 2005, p. 19). O último deles, ocorrido em 1890, deixou boa parte dos arquivos judaicos relegada às cinzas. O incêndio de 1917 por sua vez consumiu trinta e duas sinagogas, nove bibliotecas rabínicas, oito escolas judaicas e milhares 
de residências. De um dia para o outro, aproximadamente 50.000 judeus, 15.000 cristãos e 10.000 muçulmanos residentes de Salônica perderam suas casas (STEIN, 2019, p. 71). A situação de pobreza decorrente do incêndio empurrou parte significativa da população judaica para bairros periféricos desprovidos de infraestrutura básica na zona oeste da cidade. A reconfiguração étnico-geográfica de Salônica implementada nos planos urbanísticos desenvolvidos após o grande incêndio de 1917 marginalizou vários setores da comunidade judaica. Não obstante, também argumentou-se que o novo plano urbanístico privilegiou certos segmentos da comunidade, proporcionando a algumas das famílias judaicas mais abastadas da cidade a oportunidade de solidificar seu poder e influência, às vezes às custas das massas de correligionários empobrecidas (ROZEN, 2017, em NAAR, 2018, p. 553). A situação desfavorável impulsionou movimentos migratórios, de modo a produzir o ponto de inflexão que assinalou o início do declínio demográfico da comunidade que, no seu apogeu numérico, contou com cerca de 80.000 almas. $^{3}$

Figura 1: Salonique, Incendie du 18 aoút 1917

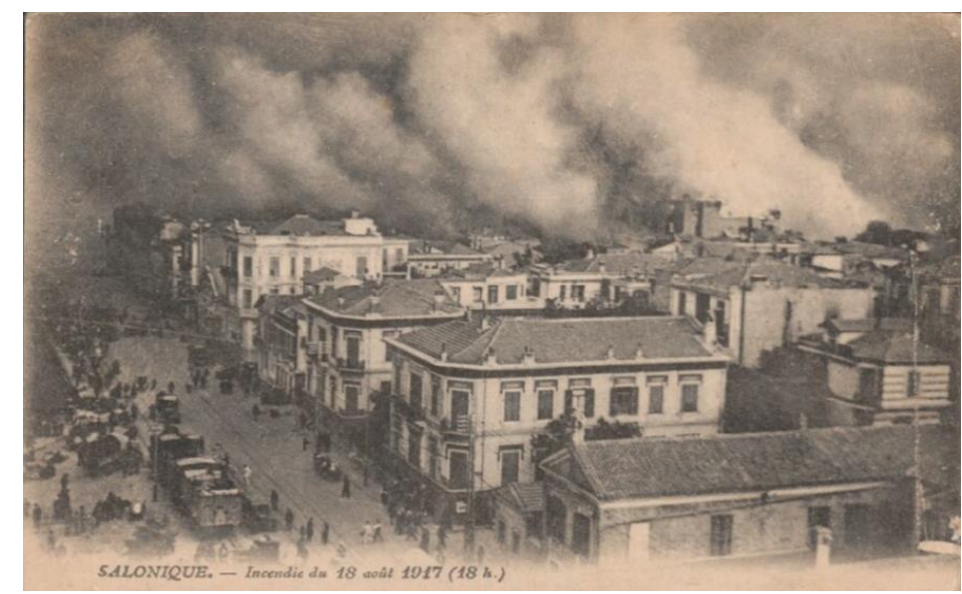

Fonte: Greece: Salonica/Selanik/Thessaloniki postcard collection, postcard 186, Duke University Library. Disponível em: <https://idn.duke.edu/ark:/87924/r4v120r18>. Acesso em: 09/05/2021.

Devido ao impacto cultural da Alliance Israélite Universelle, instituição de ensino fundada em Paris em 1860 com a missão de apoiar a educação e modernização das populações judaicas espalhadas pelo império otomano, a capital francesa era um dos destinos mais

\footnotetext{
${ }^{3}$ As vicissitudes dos judeus de Salônica após o grande incêndio reverberam no mundo lusófono através da conferência proferida por Moses Amzalak (1892-1978) em Lisboa em dezembro de 1917 a pedido de uma comissão de senhoras que promoveu a arrecadação de donativos para os israelitas de Salônica e Jerusalém. O acadêmico lisboeta calculou que o incêncio de Salônica causou um prejuizo equivalente a 750 milhões de francos (AMZALAK, 1923, p. 18).
} 
atraentes aos olhos dos judeus salonicenses que possuíam suficiente mobilidade socioeconômica para imigrar. No mesmo sentido, a cidade portuária de Marselha também cativou as esperanças dos salonicenses de fé mosaica, entre eles Jacques Stroumsa (19132010), autor da autobiografia Violoniste à Auschwitz (Violinista em Auschwitz). ${ }^{4}$ Conforme indicado por Rena Molho, no início do século XX a influente Alliance já havia estabelecido nove escolas judaicas em Salônica, e em 1912 outras dezenove também já haviam adotado o sistema de ensino propagado pela instituição francesa. O principal idioma de ensino da Alliance era o francês, muito embora algumas matérias também fossem ministradas em judeo-espanhol - versão judaica do castelhano também conhecida pelo nome de Ladino ou Judezmo (MOLHO, 2003, 14). Ironicamente, a imigração para Paris revelar-se-ia uma armadilha, já que uma parcela dos judeus salonicenses radicados na cidade-luz seria deportada para o campo de trânsito de Drancy, e posteriormente enviada a campos de concentração e extermínio. As deportações ocorreram sobretudo após a rafle des Grecs (encarceramento massivo de gregos) levada a cabo contra os judeus parisienses de nacionalidade helênica em novembro de 1942 (conferir KLARSFELD, 1978, e PINOL, 2019). Apesar do impacto cultural francês, a cidade de Nova York também atraiu muitos dos salonicenses já a partir da primeira década do século XX. Em uma coluna publicada em 1904 no jornal judeo-espanhol La Epoca de Salônica, um certo Moshe Emanuel Matalon aconselhava a juventude da comunidade a não imigrar para Paris e outras grandes cidades europeias, senão para a América ou outras regiões distantes, onde era possível alcançar uma situação econômica estável mais rapidamente (MATALON, 1904, p. 4, citado em MAYS, 2020, p. 31). La Epoca, alias, foi um dos trinta e cinco jornais publicados em Salônica entre 1865 e 1925 no idioma judeo-espanhol, vários deles jornais satíricos. Adicionalmente, cinco jornais judaicos escritos em francês também circularam em Salônica no mesmo período (MOLHO, 2003, p. 14). Podemos concluir que de fato alguns jovens escutaram o conselho de Matalon, já que em 1916 havia suficientes judeus de origem salonicense em Nova York ao ponto de poderem fundar sua própria associação, a Salonician Brotherhood of America. Não obstante, Paris continuou sendo um destino popular, conforme atestado em outro jornal judaico de Salônica, Aksion, cuja edição de 13 de abril de 1932 indicava que entre 3.000 e 4.000 integrantes da burguesia judaico-salonicense haviam emigrado para a capital francesa antes de 1921, levando consigo uma fortuna estimada em 120 milhões de francos (MOLHO, 2002, p. 190). Este dado apoia a hipótese da intersecção entre o holocausto dos judeus de Salônica e sua situação de pobreza. De qualquer modo, nada garante

\footnotetext{
${ }^{4}$ Sobre a presença sefardita em Marselha na primeira metade do século XX conferir Xavier Rothéa (2019).
} 
que os sefarditas salonicenses radicados em Paris não migrariam novamente para outras partes da Europa ou do Novo Mundo. Além da imigração salonicense para os Estados Unidos, estudada por Devin E. Naar (2007) e outros, um país distante adicional, a Argentina, também conheceu um influxo de indivíduos oriundos de Salônica (conferir LEIBIUSKY, 2019). Devido à presença de associações sionistas em Salônica, lugares como Tel Aviv e Haifa também receberam imigrantes oriundos da cidade balcânica. ${ }^{5}$

\section{De maioria a minoria}

A demografia étnica de Salônica se modificaria radicalmente a partir de 1923 devido à crise de refugiados oriundos da Ásia menor deflagrada com as chamadas "trocas de população" entre Grécia e Turquia. Cerca de 100.000 refugiados cristãos gregos se estabeleceram em Salônica, de modo que, pela primeira vez em quatrocentos anos, judeus deixaram de ser maioria na pérola do mar Egeu. ${ }^{6}$ De todas formas, a presença judaica em Salônica seguiu sendo significativa durante o período entreguerras. Apesar da pobreza que assolava a comunidade e o declínio demográfico, os judeus locais adaptaram-se à nova situação e se encontravam em todas as camadas da pirâmide social - atuando tanto como bem-sucedidos empresários (MERON, 2011) quanto como humildes trabalhadores portuários (SROUGO, 2014).

Não obstante, medidas governamentais de cunho nacionalista que priorizaram a etnia cristã-grega impuseram novos desafios a determinados setores da comunidade judaica. $\mathrm{O}$ fechamento do porto da cidade aos domingos, decretado por lei em 1924, abalou as oportunidades de negócios de muitos integrantes da comunidade, que não podiam dar-se ao luxo de deixar de trabalhar dois dias por semana. Durante séculos o porto de Salônica, um dos mais ativos de toda a bacia mediterrânea e elo de ligação entre o ocidente e o oriente, não operava aos sábados, dia do descanso judaico, pois vários dos cargos relativos ao comércio

\footnotetext{
5 A primeira associação sionista criada em Salônica, Kadimah, foi fundada em 1899 por David Florentin (18741941), editor do jornal sionista El Avenir. Novas associações foram criadas posteriormente, algumas delas investidas no projeto de construção de um lar nacional judaico na Terra de Israel, outras portadoras de um discurso sionista-cultural que não atuava necessariamente em favor da migração à Terra Santa. Também havia associações judaicas não-sionistas que defendiam a integração dos sefardim à cultura e sociedade locais. Cabe lembrar que David Ben-Gurion (1886-1973) visitou Salônica em novembro de 1911 e residiu na cidade por alguns meses antes de mudar-se a Istambul.

${ }^{6}$ Para mais detalhes sobre a instalação dos refugiados cristãos gregos em Salônica, conferir Mark Mazower (2005, p. 333-346).
} 
marítimo eram desempenhados pelos sefardim, entre eles a profissão de hammal (estivador, em judeo-espanhol, via turco). ${ }^{7}$

Um evento trágico ocorrido em 1931 marcaria profundamente a comunidade judaica local. O acampamento Campbell, erguido na periferia de Salônica para abrigar os sefardim empobrecidos após o incêndio de 1917, sofreu um ataque considerado o primeiro ato concreto de violência antijudaica maciça na cidade. Uma turba furiosa formada por cerca de 2.000 indivíduos incendiou o bairro, deixando mais de cinquenta casas, uma sinagoga, escola, e farmácia relegadas às cinzas. Estima-se que cerca de duzentas famílias se viram obrigadas a abandonar o bairro, conforme a reportagem do correspondente da Jewish Telegraphic Agency Gershon Agronsky divulgada no dia seguinte ao ataque - que comparou o evento aos ataques sofridos pela comunidade judaica de Hebron em 1929 (AGRONSKY, 1931, conferir também NAAR, 2018, p. 556). O traumático ataque abriu uma chaga na imagem da cidade como um porto seguro para sua população hebraica, impulsionando novas ondas de migração entre os sefardim salonicenses. A imigração coordenada pela família Recanati na década de 1930, por exemplo, conduziu cerca de 10.000 judeus salonicenses a Haifa e Tel Aviv, entre outras localidades da Palestina Britânica (BOWMAN \& BENMAYOR, 2002, p. 9). Estima-se que mais de 20.000 judeus gregos emigraram nas décadas de 1920 e 1930, particularmente para o Oriente Médio, França, Itália e América do Sul (FLEISCHER, 2005, p. 204, n. 59).

Figura 2: Judeus refugiados deixando suas casas após o ataque contra o acampamento Campbell

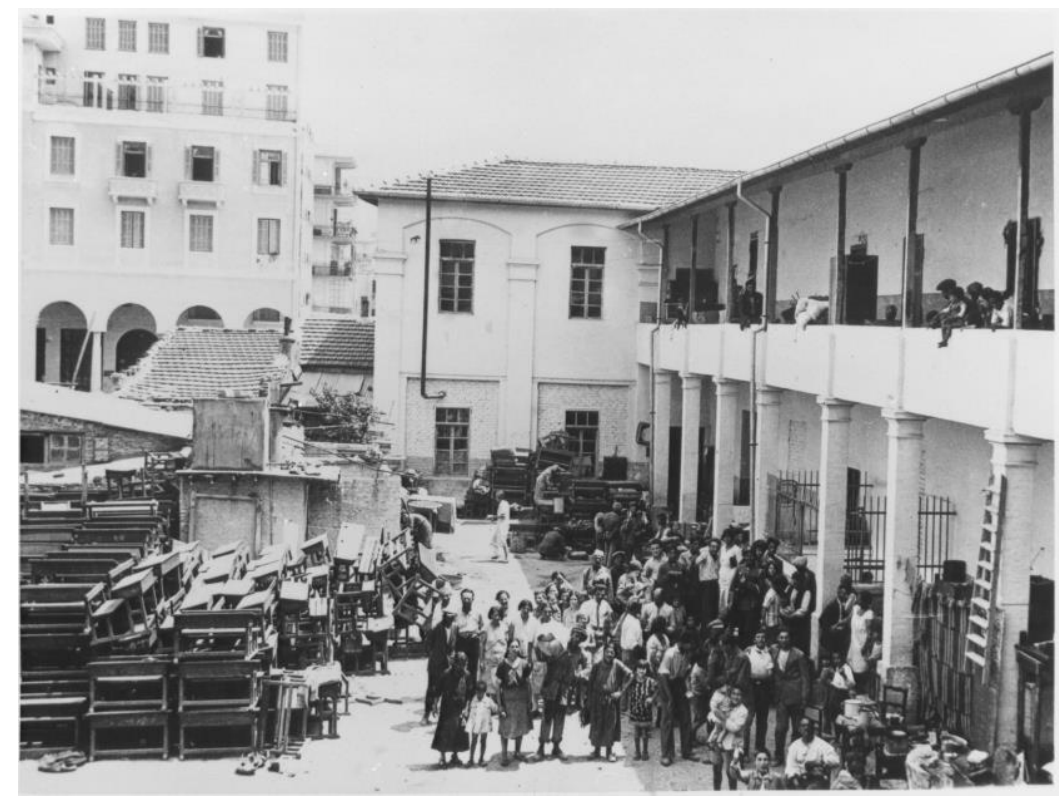

7 Apesar da fragmentação política e socioeconômica da comunidade judaico-salonicense, as principais organizações comunitárias, com exceção dos judeus socialistas, reuniram-se para protestar ante a Liga das Nações contra a imposição do fechamento do comércio aos domingos (NAAR, 2018, p. 553). 
Fonte: U.S. Holocaust Memorial Museum, photograph number: 66048. Disponível em: <https://collections.ushmm.org/search/catalog/pa3544>. Acesso em: 09/05/2021.

\section{Segunda Guerra Mundial}

Em 1939 Salônica ainda contava com uma população judaica de aproximadamente 60.000 indivíduos, a maioria deles vivendo abaixo da linha de pobreza. Quando a Segunda Guerra Mundial eclodiu, o Primeiro-Ministro grego Ioannis Metaxas (1871-1941) tentou manter seu país neutro no conflito. Não obstante, em 28 de outubro de 1940 Metaxas rejeitou o ultimato de Benito Mussolini (1883-1945) para a rendição da Grécia ante as forças fascistas italianas posicionadas na fronteira entre a Grécia e a Albânia. Desse modo, a Grécia associavase aos países Aliados e entrava na guerra. Na mobilização que se seguiu ao ultimato italiano, milhares de judeus de diferentes partes da Grécia alistaram-se no exército nacional. Jornais judaicos de Salônica divulgaram repetidas chamadas em defesa da pátria grega (FLEISCHER, 1995, p. 193) - fato que aponta a identificação da comunidade, ou pelo menos de certos segmentos dela, com a nação helênica. Um dos batalhões do regimento militar número 50 do exército grego foi chamado de "batalhão Cohen" por causa do grande número de judeus que serviram em suas fileiras (MATSAS, 1991, p. 56, KONSTANTOPOULOU \& VEREMIS, 1999, p. 34, n. 23). Baseando-se em números compilados pela comunidade judaica de Salônica a partir de estatísticas divulgadas pelo Ministério de Guerra da Grécia em novembro de 1946, Isaac Kabeli reportou que 12.898 judeus de diferentes partes da Grécia alistaram-se no exército grego, entre eles 343 como oficiais do exército, dois como tenente-coronel, e um como coronel. Esses judeus combateram contra o exército italiano na frente de batalha albanesa - conflito que ficou conhecido como a Guerra Greco-Italiana (transcorrida entre outubro de 1940 e abril de 1941) - e também contra o exército alemão na frente de batalha macedônia. Conforme Kabeli, um total de 613 judeus perderam suas vidas e 3.734 foram feridos servindo o exército helênico. Entre os feridos, 1.412 ficaram completamente incapacitados, e 862 parcialmente incapacitados (KABELI, 1953, p. 281). É importante notar que o artigo de Kabeli foi recebido com desconfiança por muitos judeus gregos devido à participação do autor no Judenrat (conselho judaico) de Atenas (LEWKOWICZ, 2006, p. 185, nota n. 6). Não obstante, os números fornecidos por Kabeli foram reproduzidos de forma acrítica por diversos pesquisadores. ${ }^{8}$

\footnotetext{
${ }^{8}$ Asher Moisis (1967, p. 183-185), Steven Bowman (1986, p. 48, 2002, p. 12), Joshua Plaut (1996, p. 55), Photini Kōnstantopoulou \& Thanos Veremis (1999, p. 34), e Rena Molho (2005, p. 287). De todos modos, Michael Matsas (1997, p. 426) e Steven Bowman (2009, p. 277, n. 56) notaram a tendência geral de Isaac Kabeli ao exagero. 
Levando em conta a estimativa de Michael Molho (1973, p. 46) segundo a qual cerca de 4.000 judeus salonicenses serviram na frente de batalha albanesa contra os italianos, Harry D. Dinella (2009, p. 88) concluiu que 12.898 judeus alistados nas fileiras do exército grego durante a Segunda Guerra Mundial parece ser um número exagerado, pois representaria quase $16.5 \%$ do total da população judaica da Grécia então (78.000 indivíduos). Posto isso, Dinella (idem, p. 89) estimou que o número total de judeus no exército grego durante a Segunda Guerra Mundial girou em torno de 6.700 .

Como se não bastassem os traumas das batalhas travadas corpo-a-corpo nos pântanos da Albânia, a maioria dos soldados judeus-salonicenses retornaria à cidade natal em abril de 1941 sem saber que o pior ainda estava por vir - pois ninguém pode adivinhar o futuro. Salvo exceções, a trajetória da maior parte desses soldados vem sendo amplamente ignorada nos estudos historiográficos. Essa lacuna resulta tanto da dificuldade de localizar documentos, espalhados em diferentes arquivos mundo afora, como de barreiras linguísticas, isto é, a falta de conhecimento do idioma grego entre pesquisadores estrangeiros. Podemos presumir que, além da pilhagem perpetrada pelos alemães, a situação de pobreza extrema dos judeus salonicenses também dificultou a preservação de documentos. Em setembro de 1940, cerca de 48.000 judeus viviam em Salônica, dos quais um total de 31.036 eram considerados "necessitados" financeiramente, número que cresceu ainda mais durante o confronto grecoitaliano (SROUGO, 2020, p. 362, conferir também RIVLIN, 1995, e HEKIMOGLOU, 2002). Este dado socioeconômico apoia a hipótese de que a situação de pobreza generalizada, traumatizante por si só, estabeleceu condições para o rápido confinamento da comunidade em guetos e subsequente deportação para os campos da morte. A falta de acesso a informação também foi determinante nesse sentido, conforme demostrou Michael Matsas (1997) em sua pesquisa conduzida em arquivos governamentais dos Estados Unidos e Inglaterra.

\section{Ocupação alemã, exacerbação da pobreza e extermínio}

O exército alemão ocupou Salônica em 9 de abril de 1941. Nos primeiros dez dias de ocupação, autoridades alemãs fecharam os escritórios das comunidades judaicas e também a imprensa. Os líderes da comunidade foram encarcerados e os arquivos e bibliotecas confiscados. O rabino-chefe da comunidade, Tzvi Koretz (1884-1945), foi detido em Atenas e

Conforme Matsas (idem), Isaac Kabeli "was persona non grata among the American diaspora of Greek Jews due to his service in the Athens Judenrat. The exaggerations in the essay [The Resistance of the Greek Jews] may be part of his postwar apology". 
enviado a uma prisão da Gestapo em Viena, retornando a Salônica somente em fevereiro de 1942 (MOLHO \& WHITE, 2012, p. 1844). Não obstante, conforme argumentaram Michael Matsas (1997, p. 33) e Hagen Fleischer (2005, p. 194), a ausência de uma repressão coletiva ostensiva contra os judeus durante o primeiro ano da ocupação produziu uma ilusória sensação de segurança. Nomeado pelos alemães em abril de 1941, o novo Primeiro-Ministro grego Georgios Tsolakoglou (1886-1948) reforçou essa sensação de segurança ao declarar que não havia uma questão judaica na Grécia. Tsolakoglou inclusive agradeceu o patriotismo dos judeus que combateram no conflito greco-italiano na Albânia, e afirmou que os cidadãos de religião judaica iriam ser tratados da mesma maneira que os cidadãos de outras religiões (MOLHO, 1973, p. 51, MATSAS, 1997, p. 31).

De qualquer forma, certas medidas preparatórias já indicavam a criação de esquemas sinistros, por exemplo a fundação do jornal fascista Nea Evropi (Nova Europa), assim como a criação do chamado Jewish Affairs Commission (conhecido também como Rosenberg Commando), responsável não somente por confiscar tesouros religiosos e culturais dos judeus, mas também por reunir informação demográfica com a finalidade de exercer controle sobre toda a comunidade.

Um dos capítulos mais infames da ocupação nazista foi a destruição praticamente total do cemitério judaico de Salônica, um dos maiores e mais antigos da Europa, perpetrada com a colaboração de equipes de engenheiros. ${ }^{9}$ Outro capítulo ocorreu em 11 de julho de 1942, quando a população judaica masculina de entre 18 e 45 anos de idade, de cidadania grega e residindo em Salônica, foi convocada à Plateia Eleftherias (Praça da Liberdade), no centro da cidade, com a finalidade de ser registrada para a realização de trabalhos forçados. Após serem obrigados a ficar em pé o dia inteiro sob o sol, além de castigados eles também foram forçados a realizar exercícios militares. Alguns terminaram feridos, enquanto outros morreram (conferir MATSAS, 1997, p. 32-35). O evento traumático assinalou o início da perseguição sistemática contra a comunidade judaica local através da implementação de leis raciais, ficando conhecido na historiografia como o "sábado negro". Uma série de imagens do sábado negro obtidas pelo partisan salonicense David Sion (nascido em 1925) hoje se encontram arquivadas no United States Holocaust Memorial Museum. ${ }^{10}$

\footnotetext{
${ }^{9}$ Sobre a destruição do cemitério judaico de Salônica conferir Stella Salem (2003) e Leon Saltiel (2014).

${ }^{10}$ Conferir a entrevista com David Sion conduzida em judeu-espanhol em 1993, arquivada no Fortunoff Video Archive for Holocaust Testimonies da Yale University (EAD ID: mssa.hvt.2795, Orbis Bib: 4288798). O Fortunoff Video Archive contém atualmente um total de 23 entrevistas com sobreviventes salonicenses. As entrevistas foram coordenadas pelo jornalista Jaša Almuli, de Belgrado, e conduzidas em 1993 em judeu-espanhol, grego, francês e inglês. David Sion também foi entrevistado por Rena Molho, em 1996, em grego (entrevista arquivada na University of Southern California Shoah Foundation, interview code 8856).
} 
Figura 3: População judaica masculina adulta de Salônica reunida na Eleftheria Square pelas tropas alemãs em 11 de Julho de 1942.

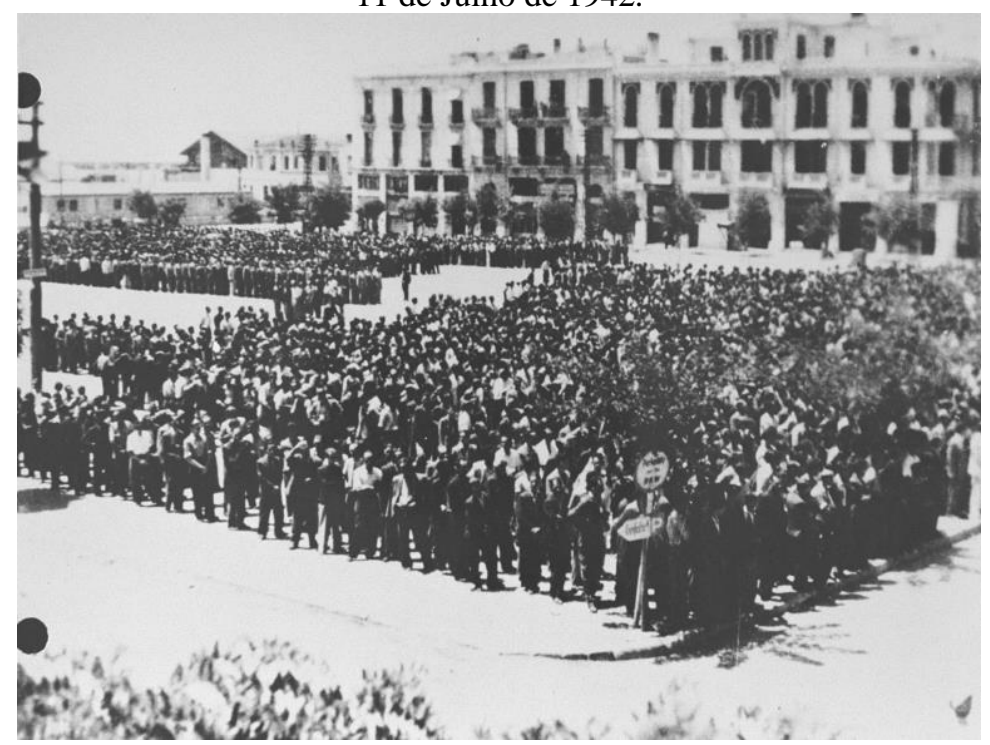

Fonte: U.S. Holocaust Memorial Museum, photograph number 33097. Courtesy of David Sion. Disponível em: <https://collections.ushmm.org/search/catalog/pa13626>. Acesso em: 09/05/2021.

Estima-se que entre 7.000 e 9.000 homens foram registrados nos dias seguintes ao sábado negro e recrutados periodicamente nos meses posteriores para a execução de trabalhos forçados. Milhares deles não sobreviveram às condições extenuantes. Àquela altura, cerca de 1.200 judeus salonicenses, a maioria deles da alta classe social, já havia escapado para áreas da Grécia sob ocupação italiana, sobretudo Atenas (FLEMING, 2008, p. 118). O período de tempo entre o sábado negro e o início das deportações, em março de 1943, comporta muitos detalhes macabros, bem como atos de resistência, estudados em detalhe por Mark Mazower (1993), Michael Matsas (1997) e Steven Bowman (2009), entre outros. Além disso, muitos documentos diplomáticos concernentes à Shoá na Grécia podem ser facilmente acessados nas coletâneas publicadas por Irith Dublon-Knebel (2007) e Daniel Carpi (2009). A preparação para a aplicação da "solução final" contra a comunidade judaica da cidade teve início em janeiro de 1943. Três áreas predominantemente judaicas serviram como gueto: Aghia Paraskevi, Regie Vardar e adjacências, e Baron Hirsch - esta última a mais próxima da estação onde, entre 15 de março e 10 de agosto de 1943, um total de 48.533 judeus gregos foram enviados para Auschwitz-Birkenau em dezenove comboios de trens. Entre eles, 37.386 foram assassinados em câmaras de gás imediatamente após chegarem ao campo. Muitos deles morreram posteriormente de fome, frio, doenças ou ferimentos causados deliberadamente por 
seus opressores, sem ter a sorte de ver o dia da libertação. Estima-se que menos de 2.000 sobreviveram (CARPI, 1999, p. 16, HADAR, 2006, p. 42). ${ }^{11}$

\section{Expressão e silêncio}

Sobreviventes da barbárie nazista lidaram com seus traumas de formas diferentes. Para alguns, como o italiano Primo Levi (1919-1987), deportado a Auschwitz-Birkenau em fevereiro de 1944 desde o campo de trânsito de Fòssoli, na região da cidade de Modena, registrar a experiência traumática para a posteridade funcionou como uma forma de "liberação interior" (LEVI, 1988, p. 8), conforme indicou no prefácio de Se questo è un uomo (É Isto Um Homem?), livro publicado em 1947 por uma pequena editora italiana e traduzido em diversas línguas após ser reeditado em 1958. Nesse relato que já nasceu clássico, Levi registrou suas impressões sobre o campo de forma pungente, porém desprovida de ódio. A narrativa inclui impressões sobre os prisioneiros judeus salonicenses que encontrou no lager, por exemplo na seguinte passagem, onde descreve o mercado informal de trocas do campo, chamado ironicamente de "Bolsa":

Os mercadores profissionais têm seu ponto na Bolsa, cada um em seu canto habitual; primeiros entre eles os gregos, imóveis e silenciosos como esfinges, acocorados atrás das gamelas de sopa espessa, fruto de seu trabalho, de suas manipulações e de sua solidariedade nacional. Os gregos já estão reduzidos a pouquíssimos; deram, porém, uma contribuição considerável à fisionomia do Campo e à gíria internacional que se fala nele. Todo o mundo sabe que caravana é a gamela; que la comedera es buena significa que a sopa está gostosa; o vocábulo que exprime a ideia genérica de furto é klepsi-klepsi, de evidente origem grega. Esses poucos sobreviventes de Tessalônica, de dupla linguagem, espanhola e helênica, e de múltiplas atividades, são os depositários de uma concreta, terrena, consciente sabedoria na qual confluem as tradições de todas as civilizações mediterrâneas. O fato de que essa sabedoria se manifesta, no Campo, com a prática sistemática e científica do roubo e da escalada aos cargos, e com o monopólio da Bolsa de trocas, não deve fazer esquecer que a repulsa dos gregos à brutalidade inútil, a sua assombrosa consciência de que ainda subsiste uma dignidade humana (ao menos, potencial), faz deles o núcleo nacional mais coerente do Campo e, sob esses aspectos, mais civilizado (LEVI, 1988, p. 115-116).

Esta e outras passagens de Se questo è un иomo, bem como trechos do segundo livro de Primo Levi, La Tregua (A Trégua, 1963), contribuíram para solidificar uma imagem idealizada

\footnotetext{
${ }^{11}$ Algumas fontes apontam 45.891 deportados, entre eles 37.387 gaseificados imediatamente após desembarcarem no campo (MOLHO \& WHITE, 2012, p. 1847).
} 
(ou estereotipada) dos judeus salonicenses que - imóveis e silenciosos como esfinges aplicaram sua sabedoria mediterrânea e coesão nacional para sobreviver no lager. Em La Tregua, Levi narra o longo e penoso caminho de volta para Turim após ser liberado do campo em janeiro de 1945. O relato inclui os encontros e desencontros com Mordo Nahum, um carismático salonicense também recém liberado de Auschwitz e dono de um amplo conhecimento mundano (conferir FLEMING, 2007, e ZEZZA, 2014, 2016).

Segundo consta, Mordo Nahum, o "super-grego" de Primo Levi, não verteu no papel sua experiência de sobrevivência no campo. Não obstante, alguns sobreviventes salonicenses resolveram deixar suas impressões no papel, entre eles o doutor Albert Menasche (1898-1991), figura proeminente da comunidade cujo texto divulgado em inglês em 1947 é considerado o primeiro relato autobiográfico publicado por um salonicense egresso de Auschwitz. Um talentoso flautista, Menasche sobreviveu como membro da orquestra do campo. Bouena Sarfatty (1916-1997) por sua vez aderiu a grupos partisans, de modo a evitar a deportação em 1943. Filha de uma família abastada de Salônica, Sarfatty compôs cerca de 500 poemas em ladino (judeu-espanhol) na modalidade poética conhecida como “coplas". Segundo Renée Levine Melammed (2013, p. 12), tradutora dos versos de Sarfatty ao inglês, o gênero poético das "coplas" foi desenvolvido no século XVIII como um tipo de literatura moral rabínica de estilo narrativo que inclui versos e rimas. Escritos cerca de trinta anos após a guerra, os versos da poetisa salonicense radicada no Canadá abordam não somente a história esplendorosa de sua comunidade, mas também os traumas enfrentados sob a ocupação nazista. Também em judeu-espanhol, as memórias do campo de extermínio escritas por Salomon Mair Uziel (18871957) circularam datilografadas a partir de 1953 e ganharam tradução ao inglês na coletânea organizada por Steven Bowman e Isaac Benmayor (2002, p. 237-280). Outro sobrevivente, Heinz Salvator Kounio, foi enviado ao campo de extermínio quanto tinha apenas 15 anos de idade junto com seus pais e irmã no primeiro comboio de trens que deixou Salônica, em 15 de março de 1943. Kounio e seus familiares sobreviveram no campo porque sabiam alemão fluentemente, de modo que foram designados para atuar como intérpretes entre seus compatriotas e os opressores nazistas. Escrito em grego e publicado em Salônica em 1981, o relato de Kounio foi traduzido ao inglês em 2003. ${ }^{12}$ As memórias de Erika Kounio, irmã de Heinz, apareceram publicadas em grego em 1995. Além das traduções ao alemão, francês, e sérvio, o texto de Erika foi traduzido ao hebraico por seu filho, Riki Amariglio (1999), e ao

\footnotetext{
12 Conferir a entrevista com Heinz Kounio arquivada no Fortunoff Video Archive for Holocaust Testimonies, Yale University (EAD ID: mssa.hvt.2784, Orbis Bib: 4288783).
} 
inglês por sua filha, Theresa Sundt Amariglio (2000). O sobrevivente Léon Perahia também redigiu seu relato em grego, publicado em Salônica em 1990 e traduzido ao francês em 2007. Iakōvos Chantali (mais conhecido como Yaacov Handeli) também decidiu deixar suas impressões no papel. Escrito em hebraico, seu livro foi publicado em Israel em 1992 e logo em seguida traduzido ao inglês com introdução assinada por ninguém menos que Elie Wiesel. Em Tu choisiras la vie: violoniste à Auschwitz (1998), Jacques Stroumsa recontou sua experiência sob ocupação nazista em Salônica, a deportação para Auschwitz, a perda da família, a atuação como violinista principal da orquestra de prisioneiros de Birkenau e o emprego como engenheiro na Weichsel-Union-Metallwerke, entre outros detalhes de sua trajetória de sobrevivência. Escrito originalmente em francês, o texto de Stroumsa foi publicado primeiramente em alemão (1993) e mais tarde em hebraico, inglês, e espanhol. O relato de Shlomo Venezia (1923-2012) sobre sua experiência em Auschwitz como integrante de um Sonderkommando (unidade de trabalho formada por prisioneiros), também redigido em francês, foi publicado em 2007. Estes e outros relatos menos canônicos aparentemente nunca foram traduzidos ao português, de modo que permanecem praticamente desconhecidos para o público lusófono. ${ }^{13}$

Figura 4: Town plan of Thessaloniki, 1944. British Army’s Royal Engineers, Field Survey Company 512

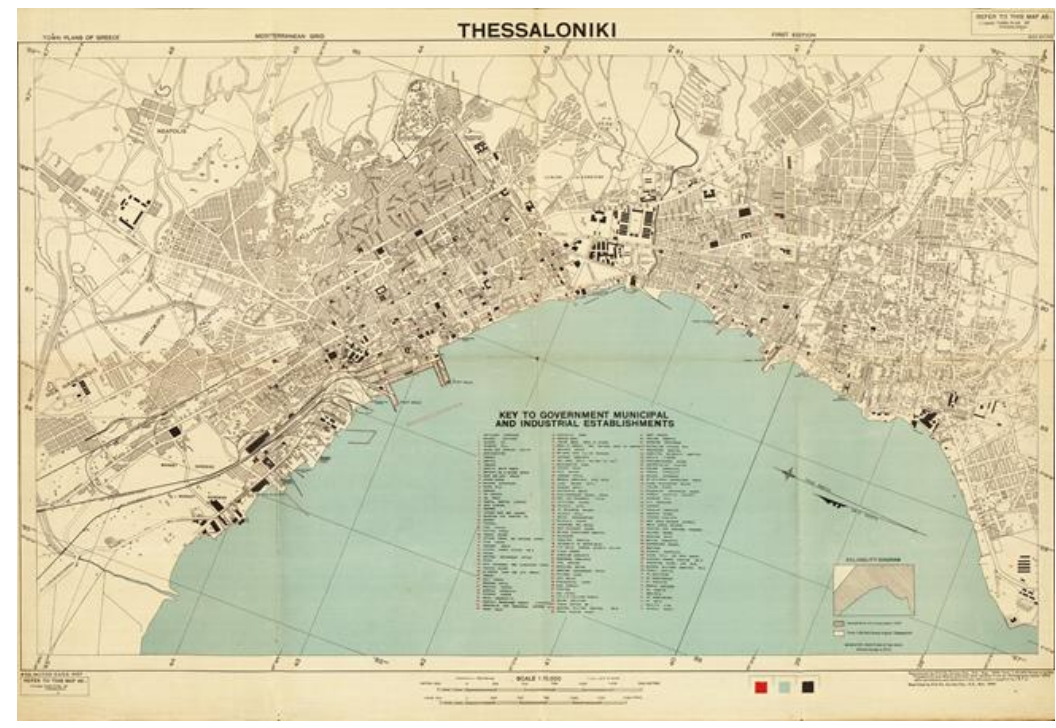

Fonte: University of Michigan Stephen S. Clark Library, call number G 6814 .T4 1944 .G71

Catalog record: <https://search.lib.umich.edu/catalog/record/010542515>.

\footnotetext{
${ }^{13}$ Segundo Steven Bowman (2009, p. 132), todos os relatos de sobreviventes gregos enfatizam três elementoschave: sorte, suporte mútuo e a determinação de sobreviver.
} 
Ao regressar à cidade natal, os menos de 2.000 judeus salonicenses sobreviventes do campo enfrentaram novas categorias de problemas, incluindo-se o advento da guerra civil grega, transcorrida entre março de 1946 e outubro de 1949. Além de ter que lidar com a experiência traumática gravada em seus corpos e almas, assim como o sentimento de culpa ou vergonha por haver sobrevivido ao extermínio brutal de seus seres queridos, em algumas circunstâncias esses sobreviventes também encararam a hostilidade tanto da população geral de Salônica quanto dos poucos correligionários locais que escaparam da deportação porque haviam se escondido ou fugido para as imediações da cidade e aderido a grupos partisans. Estima-se que pelo menos 650 judeus salonicenses evitaram a deportação escapando para as montanhas adjacentes à cidade e participando ativamente em grupos de resistência contra a ocupação alemã (KRÁLOVÁ, 2017, p. 266). Em algumas circunstâncias, os sobreviventes dos campos da morte sofreram acusações de colaboração com os nazistas, como no caso do supracitado Salomon Mair Uziel, que se viu obrigado a defender-se de acusações em diversos fóruns civis e comunitários (BOWMAN \& BENMAYOR, 2002, p. 237). Calcula-se que entre os menos de 2.000 sobreviventes salonicenses que regressaram à cidade natal, cerca 1.000 deixaram Salônica, migrando sobretudo para a Palestina britânica/Estado de Israel e os Estados Unidos. Alguns dos sobreviventes salonicenses não chegaram nem sequer a regressar à cidade natal, migrando diretamente dos campos de refugiados estabelecidos na Itália e outras partes da Europa pela United Nations Relief and Rehabilitation Administration (UNRRA) e a Cruz Vermelha. Grande parte desses sobreviventes nunca registrou por escrito nem compartilhou oralmente o que viveram, de modo que suas histórias podem ser reconstruídas somente através da documentação disponível, espalhada por diferentes arquivos em diferentes idiomas, bem como por meio das poucas informações absorvidas de forma indireta por familiares e amigos. Para esses sobreviventes, guardar silêncio foi a maneira que encontraram de lidar com as chagas traumáticas dos eventos brutais que enfrentaram. Reconstituir suas trajetórias é um desafio e também dever histórico.

As adversidades do salonicense Avram Mordoh ${ }^{14}$ (1918-1977) nunca foram divulgadas por escrito ou registradas em projetos de história oral, de modo que permanecem inéditas até hoje. Filho dos salonicenses Lea Delícia Haim (?-1943) e Emanuel Mordoh (1890?-1924?), Avram foi deportado para Auschwitz-Birkenau em 1943 junto com sua mãe e primeira esposa, Berta, filha de Baruh Galano. Conforme indicado pelos registros da comunidade judaica de Salônica, antes da deportação Avram e Berta residiam na casa número 49 da rua Promitheos,

${ }^{14}$ Mordoh, também transliterado como Mordoch. 
localizada em Régie-Vardar. ${ }^{15}$ Este bairro pobre e industrial predominantemente judaico, localizado na zona oeste da cidade, foi projetado para abrigar a classe proletária após o incêndio de 1917. Os planos urbanísticos do bairro também incluíam um distrito de entretenimento adulto. Gila Hadar, professora na Universidade de Haifa, baseou-se em fontes primárias como os jornais La Verdad, Aksion, El Popular, El Pueblo e em outros materiais disponíveis nos arquivos da comunidade judaica de Salônica para indicar que entre 1928 e 1934 as sinagogas de Régie-Vardar e do bairro adjacente Baron Hirsch funcionaram como alojamento para centenas de famílias despejadas durante o processo de reurbanização e modernização da cidade. As famílias já empobrecidas que residiam no bairro Aya Sofiya e nos barracos de Angelaki', bem como em Campbell, foram reassentadas em Régie-Vardar. Em 1934, devido à construção da nova estação central de trem e a criação de Ksirokrini, bairro destinado a abrigar refugiados cristãos-gregos, cerca de 800 famílias judias que residiam nos bairros Kabristan, Mustafa Arif e Teneke Mahale foram despejadas e realojadas em Régie-Vardar (HADAR, 2004, p. 3-4). De fato, se houvesse um equivalente sefardita do romance semi-autobiográfico Jews without Money (1930) de Michael Gold, cuja trama se desenrola no Lower East Side de Manhattan, Régie-Vardar e adjacências seriam um bom local para ambientá-lo. É possível, alias, que hajam romances assim, ainda a serem descobertos entre as centenas de publicações no idioma ancestral todavia nunca estudadas. ${ }^{16} \mathrm{Na}$ verdade, pelo menos um desses textos já nos é conhecido. Trata-se do romance de estilo realista em judeu-espanhol La Sochetá Podrida (1930), de S. Revah, cuja trama - protagonizada pela personagem Sara - se desenrola no bairro periférico Teneke Mahale e aborda a degeneração da comunidade judaica local (conferir GRUSS, 2012).

Lea Delícia e Berta foram assassinadas em Auschwitz, provavelmente nas câmaras de gás, logo após desembarcarem no lager. Segundo consta da pouca informação compartilhada por Avram, Berta estava grávida, esperando a primeira criança do casal. Avram por sua vez sobreviveu ao campo de extermínio. Documentos localizados no Arolsen Archives da Alemanha indicam que Avram foi detido em Birkenau em março de 1943, onde recebeu o número de prisioneiro 111.322. Em dezembro de 1943 Avram e outros prisioneiros detidos em Auschwitz-Birkenau foram enviados a Varsóvia para realizar trabalhos forçados nas ruinas do gueto, desmantelando os escombros que poderiam ser reciclados e utilizados como material de

\footnotetext{
${ }^{15}$ Agradeço a Aliki Arouh, arquivista da Comunidade Judaica de Thessaloniki, por fornecer esta informação via email (3 de março de 2021).

${ }^{16}$ Para um bibliografia da literatura em judeo-espanhol conferir Abraham Yaari (1934), Robert Singerman (1993) e Aviva Ben-Ur (2002).
} 
construção. O grupo enviado a Varsóvia estava constituído exclusivamente por detentos que não falavam polonês - a maiora deles gregos - de modo a dificultar a comunicação com a população local. Em julho de 1944 Avram e outros integrantes do grupo foram evacuados de Varsóvia para o campo de concentração de Dachau, localizado a cerca de dezesseis quilômetros ao norte de Munique. ${ }^{17}$ Alguns integrantes desse grupo, entre eles Avram, foram transferidos para Mühldorf, um campo satélite de Dachau. Avram foi liberado de Mühldorf em abril de 1945 após enfrentar uma marcha que aparentemente durou seis dias. Depois da liberação, Avram residiu em Feldafing - um dos primeiros campos de refugiados de guerra estabelecidos na zona de ocupação estadunidense na Alemanha. Localizado ao sul de Munique, à beira do Lago Starnberg, Feldafing foi criado para receber 3.000 judeus húngaros sobreviventes dos campos da morte, mas também acolheu sobreviventes judeus de outras nacionalidades. Foi provavelmente em Feldafing que Avram conheceu sua segunda esposa, Ella (filha de Rachel e Herman Markowitz), natural de Putnok, Hungria, e também sobrevivente dos campos de extermínio. $^{18}$

Após o período em Feldafing, Avram transitou por acampamentos de refugiados da UNRRA na Itália. Segundo o relato que circulou através da família, foi no Accommodation Center Santa Cesarea Terme - situado na província de Lecce, a aproximadamente 100 quilômetros ao sul da cidade portuária de Brindisi - que Avram reencontrou seu irmão Chaim (1913-1997), cuja trajetória durante a Segunda Guerra Mundial, também nunca antes divulgada, foi uma das mais incomuns entre os salonicenses que escaparam da perseguição impetrada pelos nazistas e seus colaboradores. Fuzileiro no exército grego, Chaim combateu na frente de batalha albanesa (1940-1941), foi ferido e feito prisioneiro dos italianos, que o enviaram para a Itália, onde, ao que tudo indica, permaneceu preso por cerca de dois anos, até setembro de 1943 aproximadamente. Naquele mês Benito Mussolini (1883-1945) foi destituído do poder e os carcereiros italianos abriram as portas da prisão onde Chaim encontrava-se detido. Uma vez liberado, Chaim dirigiu-se a uma igreja e com a ajuda de um padre obteve documentos italianos forjados (passando a chamar-se Franco Vitali) e passagens de trem para a região de Como, na fronteira com a Suíça, entrando a pé naquele país por meio de um caminho

\footnotetext{
${ }^{17} \mathrm{O}$ salonicense Isaak Mevorah (prisioneiro número 137.071 em Auschwitz) aparentemente fez parte desse grupo. Mevorah foi detido em Dachau em 1944 e teve seu certificado de liberação assinado em 28 de julho de 1945. Isaac Mevorah Collection, U.S. Holocaust Memorial Museum, accession number 2017.373.1. Disponível em: $<$ https://collections.ushmm.org/search/catalog/irn564012\#?rsc $=147002 \& \mathrm{cv}=0 \& \mathrm{c}=0 \& \mathrm{~m}=0 \& \mathrm{~s}=0 \& \times \mathrm{xwh}=-266 \%$ 2C-30\%2C2958\%2C1938>. Acesso em: 11/05/2021.

18 Segundo Steven Bowman (2009, p. 223), cerca de duzentos judeus gregos, a maioria deles salonicenses, residiram em Feldafing após serem liberados de Dachau e Mühldorf. Sobre Feldafing conferir o relato da funcionária da UNRRA Francesca M. Wilson (1947) e o estudo de Simon Schochet (1983).
} 
cercado com arame farpado, segundo relatou a seus filhos. ${ }^{19} \mathrm{Um}$ documento de identidade localizado no Arquivo Federal Suíço confirma que Chaim entrou no país helvético em novembro de 1943 , onde residiu com o status de refugiado militar até o fim da guerra. ${ }^{20}$ Chaim chegou de volta a Salônica em agosto de 1945, permanecendo na cidade por um curto período de tempo, já que naquele mesmo ano, talvez usando seus documentos italianos forjados, entraria de novo na Itália - aparentemente com a finalidade de procurar o irmão Avram.

Segundo a história que circulou entre a família, foi Avram quem apresentou Chaim a Golda, uma sobrevivente da Shoá que também estava residindo no Accommodation Center Santa Cesarea Terme. Nascida e criada em Vilna, Lituânia, Golda esteve detida em diversos campos de concentração alemães e foi a única entre os seis filhos de Rachel Dzenzelska e Hirsch Swirski a sobreviver à guerra. Golda também havia perdido o marido, Samuel Hochstein, e a filha deles, Dina, nascida em 1941 e levada pelos nazistas em uma operação contra as crianças do gueto de Vilna em 1944. Golda e Chaim se casaram no Accommodation Center Santa Cesarea Terme no dia 11 de fevereiro de 1946 e obtiveram passaportes brasileiros expedidos pela Cruz Vermelha Internacional em Roma no dia 28 de junho de 1946.

Os irmãos salonicenses recém-reunidos logo voltaram a se separar pois em agosto de 1946 Avram e a esposa Ella zarparam a bordo do Four Freedoms, navio que partiu do porto de Boca di Magra, no noroeste da Itália, com 1.024 imigrantes rumo à Palestina britânica. O Four Freedoms foi um dos vários navios que partiram da Europa em direção à Palestina britânica no contexto da onda de imigração clandestina - conhecida como Aliyah Bet - de judeus refugiados, muitos deles sobreviventes da Shoá, ocorridas antes do estabelecimento do Estado de Israel. Um Memorandum of personal data confidencial de duas páginas emitido pela Palestine Police Force indica que Ella desembarcou na Palestina britânica no dia 13 de setembro de $1946 .{ }^{21}$ Um memorandum adicional indica que Avram desembarcou na Palestina britânica tão somente em 11 de dezembro de 1946. O atraso de seu desembarque se deveu ao tempo em que esteve detido em um acampamento de refugiados em Chipre, onde as autoridades

\footnotetext{
19 Apesar da neutralidade e silêncio do Vaticano durante a Segunda Guerra Mundial, aparentemente existe evidência que o Papa Pio XII (Eugenio Pacelli, 1876-1958) instruiu secretamente a igreja a fornecer ajuda aos judeus, salvando assim milhares de vidas. Para um panorama da controvérsia conferir José M. Sánchez (2002). Conferir também Paul Hagouel (2020).

${ }^{20}$ Schweizerisches Bundesarchiv, Eidgenössische Kommission für Internierung und Hospitalisierung, archival position E5791\#1988/6\#1*. Agradeço a Guido Koller do Federal Department of Home Affairs do Arquivo Federal Suíço por localizar e facilitar a obtenção deste documento.

21 U.S. Holocaust Memorial Museum, RG-68.067M, Person id 9985046. Catalog record: <https://www.ushmm.org/online/hsv/person_view.php?PersonId=9985046>.
} 
britânicas manteram dezenas de milhares de passageiros-imigrantes dos vários navios que interceptaram.

Figura 5: Primeira página do Memorandum of personal data confidencial de Avram Mordoh emitido pela Palestine Police Force em dezembro de 1946.

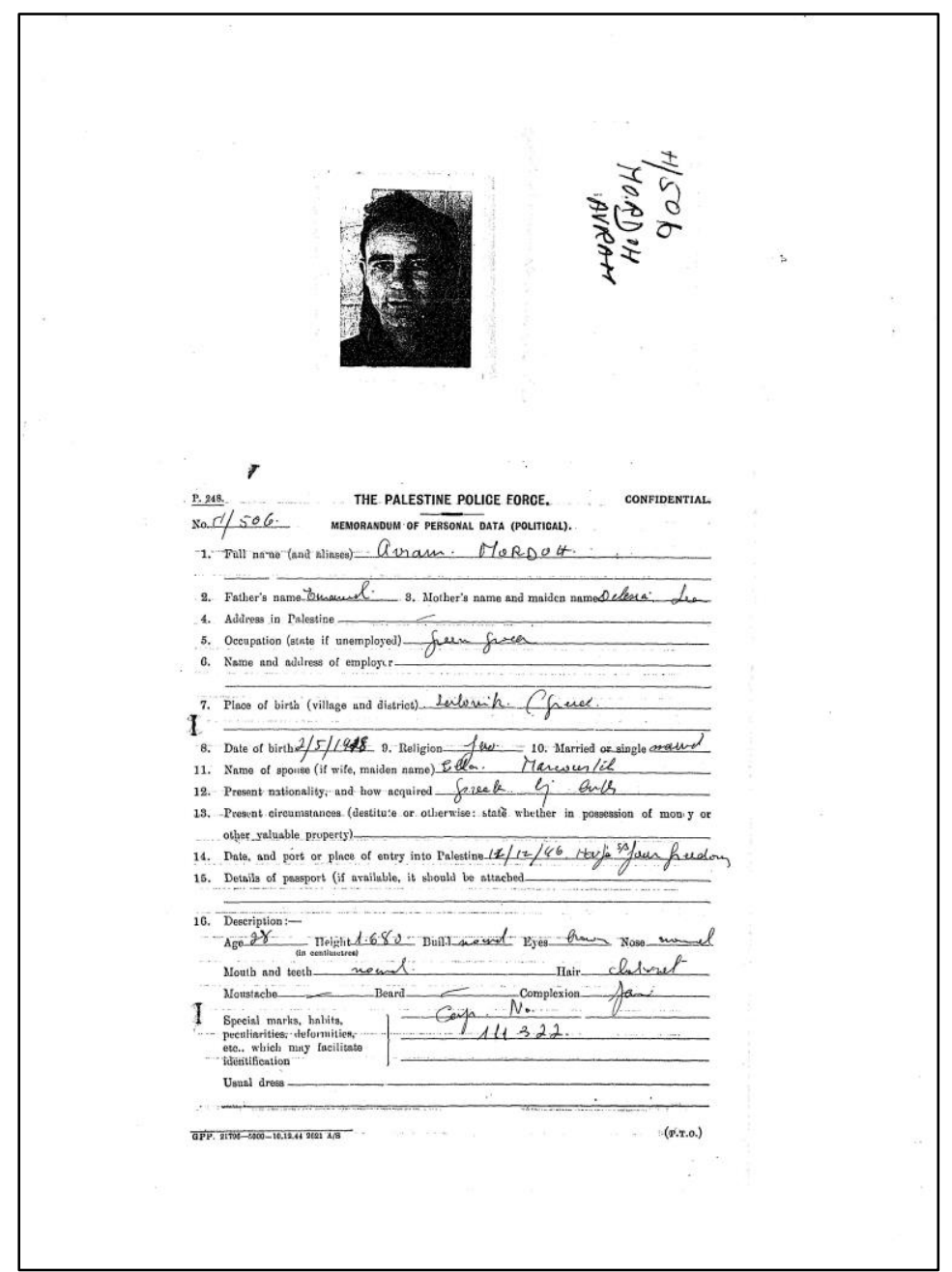

Fonte: U.S. Holocaust Memorial Museum, RG-68.067M, Person id 9985135.

Catalog record: 〈https://www.ushmm.org/online/hsv/person_view.php?PersonId=9985135>.

Avram, Ella e o filho deles (Emanuel, nascido em 1947) permaneceram em Tel Aviv até 1955, quando imigram para a cidade de São Paulo, onde Chaim e Golda haviam chegado no começo de 1947 e estabelecido residência no bairro do Bom Retiro após uma estadia de alguns meses na cidade de Buenos Aires. Chaim e Golda tiveram dois filhos (Emanuel e Horácio, nascidos em 1947 e 1950). Os irmãos salonicenses sobreviventes da Shoá na Grécia, ora reunidos novamente, viveram no Bom Retiro com suas famílias pelo resto de suas vidas - sem nunca mais voltar a pisar na cidade que os viu nascer e crescer. Essas e muitas outras trajetórias pessoais dos judeus pobres de Salônica permanecem amplamente desconhecidas e inacessíveis. 
Uma vez resgatadas, essas histórias silenciadas podem contribuir para o entendimento da formação, reminiscências e desdobramentos de uma comunidade destruída quase completamente durante a guerra.

\section{Segunda (e terceira) geração}

Um aspecto todavia pouco pesquisado em relação à ruína da comunidade judaica de Salônica é o trauma intergeracional entre os descendentes dos sobreviventes, também chamados de "segunda geração" - termo que sugere a transmissão automática, quase genética, e indesejada, da condição de sobrevivente. No universo dos sobreviventes da Europa central e oriental, o trauma intergeneracional foi representado artisticamente na série de história em quadrinhos Maus, criada a partir da década de 1980 pelo cartunista estadunidense filho de judeus poloneses Art Spiegelman (1948). Assim como entre as comunidades de sobreviventes oriundos da Europa central e oriental, é possível supor que o trauma intergeneracional também causou um ímpeto para a investigação histórica entre filhas e filhos de sobreviventes criados em Salônica à sombra da catástrofe e no entorno de seus escombros emocionais e materiais. Exemplos incluem Rena Molho, historiadora premiada nascida em 1946, e Jacky Benmayor, investigador das ruínas do cemitério judaico destruído pelos nazistas, cujos fragmentos de lápides profanadas podem ser encontrados hoje em dia ao longo de toda a cidade de Salônica, embutidos na construção de igrejas, edifícios e calçadas.

Figura 6: Calçada construída com lápides profanadas do cemitério judaico de Salônica, 1946.

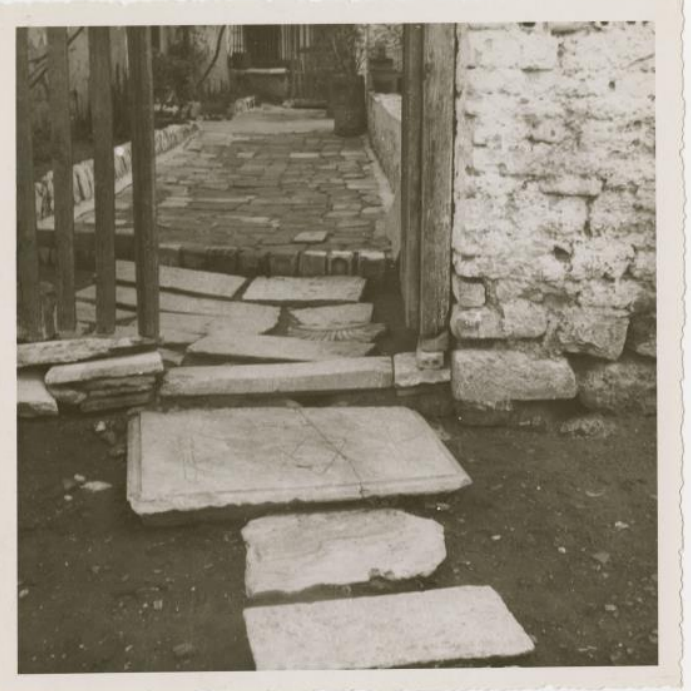

Fonte: U.S. Holocaust Memorial Museum, photograph number 00787. Disponível em: <https://collections.ushmm.org/search/catalog/pa1181559>. Acesso em: 09/05/2021. 
No Estado de Israel, a Shoá (Holocausto) foi um assunto tabu até o início da década de 1960. A partir do julgamento do criminoso de guerra Adolf Eichmann (1906-1962), ocorrido em Jerusalém em 1961, a Shoá foi incorporada ao discurso público israelense e hoje forma parte essencial da identidade nacional. Entre os sobreviventes salonicenses que se estabeleceram em Tel Aviv encontramos Haim Refael, fundador da delicatessen homônima localizada no número 36 da rua Levinski, na zona sul de Tel Aviv - região onde muitos dos seus compatriotas se instalaram antes e depois da guerra, sobretudo no bairro outrora proletário e agora boêmio chamado Florentin. Atualmente pelo menos dois dos filhos de Haim Refael e Esther Vivante, oriunda da ilha grega de Corfu, dedicam-se à investigação da história e memória das comunidades greco-judaicas dizimadas na guerra: Shmuel Refael, professor na Universidade Bar-Ilan, autor de vários estudos - um deles acerca da poesia em judeo-espanhol sobre o Holocausto (2008) - e organizador da coletânea de testemunhos Routes of Hell: Greek Jewry and the Holocaust (1988, em hebraico), e Simcha Refael-Yosef, coordenadora de grupos de conversação em judeo-espanhol. Recentemente, Simcha foi entrevistada no programa semanal de rádio Kan Ladino, e forneceu uma impressão pungente da sua condição de filha de sobreviventes: "Nossos pais chegaram tatuados nos braços, nós [filhos] ficamos com tatuagens no coração". 22

Nascido em Haifa em 1950, o músico Yehuda Poliker é famoso não somente por haver introduzido belas melodias gregas na música israelense, mas também pela sua condição de filho de sobreviventes salonicenses que aportaram na Palestina britânica em 1947. As canções de seu terceiro álbum, lançado em 1988 com o sugestivo título Efer ve-avak (Cinza e pó) - cuja capa retrata um jovem de costas observando um vagão de trem em movimento - incorporam temas relacionados à Shoá e o impacto emocional sofrido pelas filhas e filhos de sobreviventes. Além de expressar sua aflição e angústia através da música, Poliker publicou uma autobiografia cujo título poderia ser traduzido como Minha Sombra e Eu: Cenas da Infância (ha-Tsel sheli ỵa-ani: temunot yaldut, no original hebraico). Nesse relato, lançado em 2019, Poliker conta que aos cinco anos de idade já percebia e absorvia, sem compreender muito bem, os traumas do pai Jako, veterano do conflito grego-italiano (1940-1941) e sobrevivente de Auschwitz. Além dos traumas da experiência no campo, Jako também carregava a dor perene de haver perdido grande parte de sua família na guerra, inclusive um filho, nascido do seu primeiro casamento. Poliker

${ }^{22}$ Kan Ladino (9 de abril de 2021, minuto 20:28). No original hebraico: "Hem 'igi'u meku'ak'aim ba-yad, anahnu nisharnu meku'ak'aim ba-lev". Disponível em: 〈https://www.kan.org.il/radio/player.aspx?ItemId=209333>. Acesso em: 09/04/2021. 
observa o passado e remonta perplexo às emoções confusas de sua infância ao escutar o pai Jako chorando:

O que fazer? O que um menino pode fazer nesta situação? Como é possível aguentar ver o pai chorando? Desespero e vazio penetram minha barriga, causando em mim um terrível sentimento de ausência. A tristeza de meu pai entra em mim profundamente e deixa em mim algo que eu ainda não sou capaz de compreender. (POLIKER, 2019, p. 13, minha tradução).

O espaço da memória e trauma naturalmente não é propriedade exclusiva dos descendentes diretos de sobreviventes. Filho de uma família instalada em Jerusalém há várias gerações, o poeta e tradutor israelense Avner Perez (1942) também buscou dar vazão a sentimentos desencontrados diante do destino melancólico dos sefardim de Salônica, expressados no ciclo de poemas bilíngues em judeu-espanhol e hebraico Siniza i fumo (Cinza e fumaça, 1986).

A "terceira geração" de sobreviventes também se interessou e por vezes absorveu as experiências traumáticas dos avós e outros parentes. O filósofo francês Edgar Morin escreveu a biografia de seu pai, o salonicense Vidal Nahum (1894-1984), baseando-se em grande medida nas gravações das entrevistas que sua filha (neta de Vidal Nahum), a historiadora Véronique Grappe-Nahoum, conduziu com o avô em 1978. Como um “neo-marrano”, Vidal disfarçou sua identidade judaica passando-se por católico, de modo a iludir a perseguição nazista em Paris e evitar a deportação para os campos da morte (MORIN, 2009, p. 175 - existe tradução brasileira). Autor de um livro premiado sobre a comunidade judaica de Salônica, o historiador estadunidense Devin E. Naar indicou que seu interesse pelo tema surgiu da profunda curiosidade pelo horizonte cultural tanto de seu avô, Isidore B. Naar (1917-2008), nascido em Salônica e emigrado para os Estados Unidos em 1924, quanto de seu tio-avô, Salomon (19031943), que pereceu em Auschwitz junto com a mulher Esther (née Pinhas) e os filhos Rachel e Benjamin (NAAR, 2016, p. xii). Deniz Bensusan, jovem sefardita de Istambul e protagonista do documentário The Final Hour lançado em 2019 pelo diretor Caglar Malli, percorreu cidades onde o judeu-espanhol era falado cotidianamente com o objetivo de entender como e por que o idioma ancestral foi praticamente apagado do mapa. Um dos trechos mais pungentes do documentário se passa em Salônica e retrata o choque profundo experimentado pela protagonista ao descobrir que cerca de 60 integrantes de sua família residentes da cidade foram enviados para os campos da morte (MALLI, 2019, min. 17-25). O interesse da "terceira geração" pela experiência dos avós também motivou a historiadora brasileira Adriana Borges 
Calderoni a entrevistar seu avô paterno, Mosez Calderon ${ }^{23}$ (1917-2003), filho de Palomba e Sabetai Calderon. Nascido em Florina, cidade grega localizada a cerca de 170 quilômetros ao oeste de Salônica, Mosez serviu o exército grego no conflito contra os italianos na frente de batalha albanesa (1940-1941), foi prisioneiro de guerra na Itália, refugiado militar na Suíça e, assim como Avram e Chaim Mordoch, também circulou pela Itália após a guerra. Mosez imigrou para o Brasil em 1947, fixando residência na cidade de São Paulo. ${ }^{24}$

\section{Reflexões derradeiras}

Fundado em 1945 em torno dos escombros materiais e espirituais de uma Europa devastada pela guerra, o Central Board of Jewish Communities in Greece (KIS, na abreviação grega) é atualmente a principal organização da comunidade judaica da Grécia. Operando sob a jurisdição do Ministério da Educação e Religião, o KIS é responsável por coordenar as atividades comunitárias dos cerca de 4.200 judeus que residem no país hoje em dia, aproximadamente 1.000 deles em Salônica. Ao visitar a cidade em 1988, Isaac Papo (nascido em Milão em 1926) não se surpreendeu ao encontrar pouquíssimos vestígios do que outrora foi a capital econômica, social e cultural do sefardismo "oriental” (isto é, localizado na parte leste da bacia mediterrânea). A explicação oferecida pelo médico sefardita itinerante é simples:

En efecto, tras las devastaciones provocadas por el incendio, la destrucción ensañadamente perpetrada por los nazis fue total; aparte del cementerio y de las sinagogas, completamente allanados, desaparecieron documentos, archivos, incunables y objetos de culto recogidos durante siglos de intensa vida comunitaria. La destrucción fue científicamente total para borrar y erradicar de una vez para siempre aquella anomalía, constituida por una ciudad casi enteramente judía (PAPO, 2006, p. 324).

Hoje em dia, os vestígios safarditas do que foi outrora uma cidade quase inteiramente judaica são um pouco mais visíveis na paisagem local, muito embora considerados insuficientes pelos mais nostálgicos. Além de alguns monumentos dedicados às vítimas da barbárie nazista, Salônica também conta com um importante museu judaico, fundado em 2001. Recentemente, anunciou-se o projeto da criação de um imponente museu do Holocausto, de modo a

\footnotetext{
${ }^{23}$ A grafia Calderon foi alterada para Calderoni durante o período em que Mosez esteve na Itália.

${ }^{24}$ Agradeço a David Calderoni por compartilhar a transcrição da entrevista com Mosez Calderoni, colhida por Adriana Borges Calderoni em 1 de outubro de 1995 no contexto do curso Metodologia II ministrado pelo professor José Carlos Sebe Bom Meihy no departamento de História da Universidade de São Paulo.
} 
homenagear as vítimas e avançar a missão de memorialização do trauma coletivo dos judeus da cidade. Essas e outras iniciativas, tais como o oferecimento de cursos de judeu-espanhol na Aristotle University of Thessaloniki e no Instituto Cervantes da cidade, bem como o guia turístico-histórico da Salônica judaica lançado por Christos Zafiris (2016), vão aos poucos recriando na paisagem urbana reminiscências tanto esplendorosas quanto trágicas de um passado que não volta nunca mais. A catástrofe da ex-Jerusalém dos Bálcãs, hoje circunscrita puramente no reino da memória, seguirá marcando de forma atávica os corações e mentes das gerações futuras.

\section{Referências}

AGRONSKY, Gershon. Agronsky finds Saloniki Jewish Quarter after pogrom looks like Hebron following riots. Jewish Daily Bulletin, July 8, 1931.

AMZALAK, Moses. Os ideais israelitas e a guerra. Coimbra: Imprensa da Universidade, 1923.

AVNI, Haim. Spain, the Jews, and Franco. Translated from the Hebrew by Emanuel Shimoni. Philadelphia: Jewish Publication Society of America, 1982.

BEN-UR, Aviva. Ladino in Print: Toward a Comprehensive Bibliography. Jewish history, v. 16, n. 3, p. 309-326, 2002.

BOWMAN, Steven B. The Agony of Greek Jews, 1940-1945. Stanford, California: Stanford University Press, 2009.

. Jews in Wartime Greece. Jewish Social Studies, v. 48, n. 1, p. 45-62, Winter 1986.

\& BENMAYOR, Isaac. The Holocaust in Salonika: Eyewitness Accounts. New York: Sephardic House, 2002.

CARPI, Daniel (ed.). Italian diplomatic documents on the history of the Holocaust in Greece (1941-1943). Edited by Daniel Carpi. Tel Aviv: The Chair for the History and culture of the Jews of Salonika and Greece: The Diaspora Research Institute: Tel Aviv University, 1999. 
DINELLA, Harry D. The Holocaust in Northern Greece: The war against the Sephardic Jews of Thessaloniki. Dissertation submitted in partial fulfillment of the requirements for the degree of Doctor of Arts at George Mason University, 2009.

DUBLON-KNEBEL, Irith (ed.). German Foreign Office Documents on the Holocaust in Greece (1937-1944). Compiled, translated and annotated with an introduction by Irith DublonKnebel. Tel Aviv: The Chair for the History and Culture of the Jews of Salonika and Greece, The Goldstein-Goren Diaspora Research Center, 2007.

FLEISCHER, Hagen. Greek Jewry and Nazi Germany: The Holocaust and its Antecedents. In: Les Juifs en Grèce: Questions historiques dans la longue durée. Association pour l'étude des Juifs de Grèce; Actes du ler colloque d'Histoire Les Juifs en Grèce: Questions d'Histoire dans la longue durée, Salonique, 23-24 novembre 1991. Athènes: Editions Gavriilidis, 1995, p. 185206.

FLEMING, K.E. Greece: a Jewish history. Princeton, N.J.: Princeton University Press, 2010. . The Stereotyped "Greek Jew” from Auschwitz-Birkenau to Israeli Popular Culture. Journal of Modern Greek Studies, v. 25, n. 1, p. 17-40, 2007.

GERBER, Jane S. Reconstructing Sepharad in Istanbul and Salonica, 1492-1600. In: Gerber, Jane S. Cities of Splendour in the Shaping of Sephardi History. 2020. London: The Littman Library of Jewish Civilization, in association with Liverpool University Press, New York, NY: Oxford University Press, 2020, p. 171-213.

GINIO, Eyal. "Learning the beautiful language of Homer": Judeo-Spanish speaking Jews and the Greek language and culture between the Wars. Jewish History, n. 16, p. 235-262, 2002.

GOLD, Michael. Jews without Money. New York: Liveright, 1930.

GRUSS, Susy. La ciudad de Salónica: ¿una ciudad celestial o infernal? Selected Papers from the Fifteenth British Conference on Judeo-Spanish Studies. Ed. Hilary Pomeroy, Christopher 
J. Pountain and Elena Romero (London: Department of Iberian and Latin American Studies, Queen Mary, University of London, 2012), p. 115-128.

HADAR, Gila. Régie Vardar: a Jewish “Garden City” in Thessaloniki (1917-1943). Paper presented at Seventh International Conference on Urban History: European City in Comparative Perspective (Oct. 27-30, 2004). Disponível em: $<$ http://pandemos.panteion.gr/index.php?op=record\&pid=iid:510\&lang=en>. Acesso em: $16 / 05 / 2021$.

Space and time in Saloniki on the eve of World War II, and the expulsion and destruction of Saloniki Jewry, 1939-1945. Yalkut Moreshet, n. 4, p. 42-79, 2006.

HAGOUEL, Paul. Italy's Role in the Holocaust of Greek Jews. Sephardic Horizons, v. 10, n. 3-4, Summer - $\quad$ Fall 2020. Disponível em: $<$ https://www.sephardichorizons.org/Volume10/Issue3\&4/Hagouel.html>. Acesso em: $16 / 05 / 2021$.

HANDELI, Yaacov. A Greek Jew from Salonica Remembers. New York: Herzl Press, 1993.

HEKIMOGLOU, E. Jewish Pauperism in Salonika, 1940-1941. In: ROZEN, Minna (ed.). The last Ottoman century and beyond: the Jews in Turkey and the Balkans 1808-1945, v. II. 2002. Tel Aviv: The Chair for the History and Culture of the Jews of Salonika and Greece, The Goldstein-Goren Diaspora Research Center, 2002, p. 195-205.

KABELI, Isaac. The Resistance of the Greek Jews. Yivo Annual of Jewish Social Science, v. 8, p. 281-288, 1953.

KRÁLOVÁ, Kateřina. "Being traitors": post-war Greece in the experience of Jewish partisans. Southeast European and Black Sea Studies, v. 17, n. 2, p. 263-280, 2017. <https://doi.org/10.1080/14683857.2017.1324277>.

KLARSFELD, Serge. Le mémorial de la déportation des Juifs de France. Edité et publié par Beate et Serge Klarsfeld. Paris, 1978. 
KOBRIN, Nancy Hartevelt. Uriel da Costa, J. M. da Costa, M.D. What's Freud got to do with it? Or how Ladino and Sephardic culture inform psychoanalysis and trauma studies. In: BUNIS, David (ed.). Languages and Literatures of Sephardic and Oriental Jews. 2009. Jerusalem: The Bialik Institute-Misgav Yerushalayim, 2009, p. 306-318.

KŌNSTANTOPOULOU, Phōteinē, \& VEREMĒS, Thanos (eds.). Documents on the History of the Greek Jews: Records from the Historical Archives of the Ministry of Foreign Affairs. 2nd ed. Athens: Kastaniotis Editions, 1999.

KOUNIO AMARIGLIO, Erika Myriam. From Thessaloniki to Auschwitz and back: memories of a survivor from Thessaloniki. Translated into English by Theresa Sundt (née Amariglio). London: Vallentine Mitchell, 2000.

KOUNIO, Heinz Salvator. A Liter of Soup and Sixty Grams of Bread: The Diary of Prisoner Number 109565. [New York]: Published for Sephardic House by Bloch Publishing Company, 2003.

LEIBIUSKY, Javier. L'immigration Judéo-Espagnole à Buenos Aires: histoire d'une communauté invisible (1876-1930). İstanbul: Libra Kitapç1lı ve Yayıncılık, 2019.

LEVI, Primo. É Isto Um Homem? Tradução de Luigi Del Re. Rio de Janeiro: Rocco, 1988. . Se Questo è un Uomo. Torino: F. De Silva, [1947]. . La Tregua. Torino: Einaudi, 1963.

LÉVY, Isaac Jack. The Sephardim in the Holocaust: A Forgotten People. Tuscaloosa, Alabama: The University of Alabama Press, 2020.

LEWKOWICZ, Bea. The Jewish Community of Salonika: History, Memory, Identity. London: Vallentine Mitchell, 2006. 
MALLI, Çağlar (dir.). The Final Hour. Based on the story of Deniz Bensusan and her family. United Kingdom: Case Productions UK, 2019. Institutional streaming (77 min), son., color.

MATALON, Moshe Emanuel. La Imigrasion. La Epoka, 8/Jan/1904, p. 4. Disponível em: <https://www.nli.org.il/en/newspapers/lep/1904/01/08/01/?\&e=-------en-20--1--imgtxIN\%7ctxTI--------------1>. Acesso em: 16/05/2021.

MATSAS, Joseph. The Participation of the Greek Jews in the National Resistance, 1940-1944. Journal of the Hellenic diaspora, n. 17, p. 55-68, 1991.

MATSAS, Michael. The Illusion of Safety: The Story of the Greek Jews during World War II. New York, NY: Pella Pub. Co, 1997.

MAYS, Devi. Forging Ties, Forging Passports: Migration and the Modern Sephardi Diaspora. Stanford, California: Stanford University Press, 2020.

MAZOWER, Mark. Inside Hitler's Greece: The Experience of Occupation, 1941-1944. Yale University Press, 1993.

. Salonica, City of Ghosts: Christians, Muslims and Jews, 1430-1950. 1st American ed., Knopf: Distributed by Random House, 2005.

MELAMMED, Renée Levine. An Ode to Salonika: The Ladino Verses of Bouena Sarfatty. Bloomington, Indiana: Indiana University Press, 2013.

MENASCHE, Albert. Birkenau (Auschwitz II): memories of an eyewitness: how 72,000 Greek Jews perished. By Albert Menasche, number 124.454. New York, N.Y.: I. Saltiel, 1947.

MERON, Orly C. Jewish entrepreneurship in Salonica, 1912-1940: An ethnic economy in transition. Brighton; Portland: Sussex Academic Press, 2011.

MOISIS, Asher. Yehudim be-tsava Yayan. In: SLUTSKI, Yehudah, and Mordekhai Kaplan (eds.), Hayalim Yehudim bi-tsiv’ot Eropah. Tel Aviv: Ma'arakhot, 1967, p. 182-185. 
MOLHO, Michael. In memoriam: hommage aux victimes juives des nazis en Grèce. Seconde édition revue et augmentée par Joseph Nehama. Thessalonique: Communauté Israélite de Thessalonique, 1973.

MOLHO, Rena. The Jewish Community of Salonika and its incorporation into the Greek State 1912-19. Middle Eastern Studies, v. 24, n. 4, p. 391-403, Oct. 1988.

Jewish working-class neighborhoods established in Salonica following the 1890 and 1917 fires. In: ROZEN, Minna (ed.). The last Ottoman century and beyond: the Jews in Turkey and the Balkans 1808-1945, v. II. 2002. Tel Aviv: The Chair for the History and Culture of the Jews of Salonika and Greece, The Goldstein-Goren Diaspora Research Center, 2002, p. 173194.

. Judeo-Spanish, a Mediterranean language in daily use in 20th Century Salonica. In:

Cultural Forum of the Jewish Community of Thessaloniki: Ir Vaem Beisrael. Vol. 1. 2003. Greece: Ets Ahaim Foundation, Cultural Committee of the J.C.T., 2003, p. 13-29.

Salonica and Istanbul: Social, political and cultural aspects of Jewish life. Istanbul: Isis Press, 2005.

; WHITE, Joseph Robert. Thessalonikiē, aka Selanik or Saloniki. In: The United States Holocaust Memorial Museum Encyclopedia of Camps and Ghettos, 1933-1945. Vol. II, Part A, Ghettos in German-occupied Eastern Europe. Volume editor, Martin Dean; contributing editor, Mel Hecker. Bloomington: Indiana University Press, 2012, p. 1844-1848.

MORIN, Edgar. Vidal and His Family: From Salonica to Paris: The Story of a Sephardic Family in the Twentieth Century. Translated by Deborah Cowell; foreword by Alfonso Montuori. Brighton-Portland: Sussex Academic Press, 2009 [original em francês publicado em 1989, tradução ao português publicada em 2005].

NAAR, Devin E. Beyond the "Valley of Tears": Reassessing the Narrative of Decline in Salonican Jewish Historiography. Études balkaniques, v. 3, p. 536-567, 2018. 
. From the "Jerusalem of the Balkans" to the Goldene Medina: Jewish Immigration from Salonika to the United States. American Jewish History, v. 93, n. 4, p. 435-473, Dec. 2007.

Jewish Salonica: Between the Ottoman Empire and Modern Greece. Stanford, California: Stanford University Press, 2016.

PAPO, Isaac. Viaje en el ocaso de una cultura ibérica: recuerdos y reflexiones de un médico sefardí. Barcelona: Tirocinio, 2006.

PERAHIA, Léon H. Mazal, Un Salonicien Dans Les Camps de La Mort (1943-1945). Paris: Editions du Nadir; Lettre Sépharade, 2007.

PEREZ, Avner. Siniza i fumo: siklo de poemas dedikado a la memoria de Saloniko. Edision bilingue. Yerusahalayim, 1986.

PINOL, Jean-Luc. Convois: La déportation des Juifs de France. Préface de Serge Klarsfeld. Paris: Éditions du Détour, 2019.

PLAUT, J. E. Greek Jewry in the twentieth century, 1913-1983: Patterns of Jewish survival in the Greek provinces before and after the Holocaust. Cranbury, NJ: Associated University Presses, 1996.

POLIKER, Yehuda. Ha-Tsel sheli ya-ani: temunot yaldut. Tel Aviv: Sifre 'aliyat ha-gag; Rishon le-Tsiyon: Yedi'ot aharonot : Sifre ḥemed, 2019.

REFAEL, Shmuel. Un Grito en el silencio: La poesía sobre el Holocausto en lengua sefardí: estudio y antología. Barcelona: Tirocinio, 2008. . (ed.). Routes of Hell: Greek Jewry in the Holocaust: Testimonies. (Hebraico) Tel-Aviv: ha-Makhon le-ḥeḳer Yahadut Śaloniḳi ỵe-Irgun nitsole maḥanot ha-hashmadah yots'e Yaṿan be-Yiśra'el, 1988. 
REVAH, S. Sochetá podrida: shenas de la vida reala de Salonico. Salonica: Biblioteca del Escambel, 1930.

RIVLIN, Bracha. Mutual-aid societies in Greek-Jewish communities. In: Les Juifs en Grèce: Questions historiques dans la longue durée. Association pour l'Étude du Judaïsme de Grèce; Actes du ler colloque d'Histoire Les Juifs en Grèce: Questions d'Histoire dans la longue durée, Salonique, 23-24 novembre 1991. Athènes: Editions Gavriilidis, 1995, p. 95-101.

ROTHÉA, Xavier. Les Judéo-Espagnols à Marseille dans la première moitié du XXe siècle: De l'espoir à la catastrophe. Paris: Éditions Pétra, 2019.

ROZEN, Minna. Money, Power, Politics and the Great Fire of 1917. Jewish Social Studies, v. 22, n. 2, p. 74-115, 2017.

SALEM, Stella. The old Jewish Cemetery of Thessaloniki. In: $\underline{\text { Cultural Forum of the Jewish }}$ Community of Thessaloniki: Ir Vaem Beisrael. v. 1. 2003. Greece: Ets Ahaim Foundation, Cultural Committee of the J.C.T., 2003, p. 49-59.

SALTIEL, Leon. Dehumanizing the Dead: The Destruction of Thessaloniki's Jewish Cemetery in the Light of New Sources. Yad Vashem Studies, v. 42, n. 1, p. 1-35, 2014.

SÁNCHEZ, José M. Pius XII and the Holocaust: Understanding the Controversy. Washington, District of Columbia: Catholic University of America Press, 2002.

SCHOCHET, Simon. Feldafing. Vancouver: November House, 1983.

SINGERMAN, Robert. Spanish and Portuguese Jewry: A Classified Bibliography. Westport, Conn.: Greenwood Press, 1993.

SPIEGELMAN, Art. Maus a survivor's tale: my father bleeds History. New York: Pantheon Books, 1986. 
SROUGO, Shai. The Jewish Laborers in the Port of Thessaloniki: between the Ottoman World and the Greek Nation State (1869-1936). (Hebraico) Jerusalem: Yad Izhak Ben-Zvi; The Hebrew University of Jerusalem, 2014.

. The Jewish workers in the port of Thessaloniki (1939-1943): Their war experience as workers, Greeks and Jews. Journal of Modern European History, v. 18, n.3, p. 352-373, 2020. DOI: $10.1177 / 1611894420924909$.

STEIN, Sarah Abrevaya. Family Papers: a Sephardic Journey through the Twentieth Century. New York: Farrar, Straus and Giroux, 2019.

STROUMSA, Jacques. Tu choisiras la vie: violoniste à Auschwitz. Préface de Beate Klarsfeld. Paris: Les éditions du Cerf, 1998.

USQUE, Samuel. Consolação às tribulações de Israel. Ferrara: Abraham aben Usque, 1553.

VENEZIA, Shlomo Sonderkommando: Dans L'enfer des chambres à gaz. En collaboration avec Béatrice Prasquier; préface de Simone Veil. Paris: Michel, 2007.

WILSON, Francesca. M. Aftermath: France, Germany, Austria, Yugoslavia 1945 and 1946. West Drayton: Penguin Books, 1947.

YAARI, Abraham. Catalogue of Judaeo-Spanish books in the Jewish National and University Library, Jerusalem. Jerusalem: University Press, 1934 (em hebraico).

ZAFIRIS, Christos. Thessaloniki of the Jews: History, Society, Monuments. Thessaloniki: The Jewish Museum of Thessaloniki; Epikentro, 2017.

ZEZZA, Stefania. Primo Levi, Salonika and "other great Greek matters". Trauma and Memory, v. 2, n. 2, p. 50-56, 2014. 
"A man who has no shoes is a fool": The Salonikan Jews in the Concentration Camps.

Sephardic Horizons, v. 6, n. 3-4, Summer - Fall 2016. Disponível em: <https://www.sephardichorizons.org/Volume6/Issue3-4/Zezza.html>. Acesso em: 16/05/2021. 